\title{
MODEL PENDAMPINGAN GURU DALAM MENGHADAPI PELAKSANAAN UJIAN NASIONAL MATEMATIKA DI SEKOLAH INKLUSIF
}

\author{
Trisno Ikhwanudin \\ PPPPTK TK dan PLB Bandung \\ trisno.ikhwanudin@gmail.com
}

\begin{abstract}
ABSTRAK
Memandang strategisnya posisi ujian nasional, khususnya dalam mata pelajaran matematika, dirasakan perlu dikembangkan suatu model pendampingan guru dalam menghadapi pelaksanaan Ujian Nasional pada mata pelajaram Matematika di Sekolah Inklusif. Model pendampingan guru ini diawali dengan proses tes diagnostik kepada siswa kelas XII atau kelas 3 SMA Inklusi. Selanjutnya hasil tes diagnostik akan dikomunikasikan dengan guru matematika sekolah bersangkutan. Hasil tes diagnostik itu memuat kekuatan dan kelemahan siswa, dalam arti pokok bahasan/sub pokok bahasan apa saja yang dikuasai dan kurang dikuasai oleh siswa. Selanjutnya berdasarkan kelemahan siswa tersebut dilakukan treatment terhadap guru. Dalam kegiatan treatmen tersebut, guru diberi input materi tentang metode atau strategi pembelajaran untuk menyelesaikan masalah/soal pada pokok bahasan yang kurang dikuasai oleh siswa. Selanjutnya guru mengaplikasikan metode atau strategi tersebut di kelas. Dalam kurun waktu tertentu, siswa diuji kembali dengan soal yang mengacu pada Standar Kompetensi Lulusan (SKL) Ujian Nasional dan proses diatas berulang kembali sebanyak $2-3$ putaran sebelum pelaksanaan Ujian Nasional.
\end{abstract}

Kata Kunci: model pendampingan guru, ujian nasional, tes diagnostik, sekolah inklusif

\section{PENDAHULUAN}

Ujian Nasional (UN) diselenggarakan sebagai salah satu upaya untuk meningkatkan mutu pendidikan nasional. Landasan yuridisnya adalah Undang - Undang No. 20 Tahun 2003 tentang Sistem Pendidikan Nasional.

Salah satu pelajaran yang diujikan dalam UN adalah Matematika. Mata pelajaran ini menawarkan kemampuan yang sangat dibutuhkan pada era kompetitif dewasa ini, yaitu berpikir kritis, sistematis, logis, kreatif dan kemauan bekerjasama yang efektif . Cara berpikir seperti ini dapat dikembangkan melalui belajar matematika karena matematika memiliki struktur serta keterkaitan yang kuat dan jelas antar konsepnya sehingga memungkinkan siswa terampil berpikir rasional.

Memandang strategisnya posisi ujian nasional, khususnya dalam mata pelajaran matematika, penulis mengembangkan suatu model pendampingan guru dalam menghadapi pelaksanaan Ujian Nasional pada mata pelajaram Matematika untuk sekolah inklusif. 
Model pendampingan guru ini diawali dengan proses tes diagnostik kepada siswa kelas XII atau kelas 3 SMA Inklusif. Selanjutnya hasil tes diagnostik akan dikomunikasikan dengan guru matematika sekolah bersangkutan. Hasil tes diagnostik itu memuat kelemahan siswa, dalam arti pokok bahasan/sub pokok bahasan apa saja yang kurang dikuasai oleh siswa. Selanjutnya berdasarkan kelemahan siswa tersebut dilakukan treatmen terhadap guru. Dalam kegiatan treatmen tersebut, guru diberi input materi tentang metode atau strategi pembelajaran untuk menyelesaikan masalah/soal yang pada pokok bahasan yang kurang dikuasai oleh siswa. Selanjutnya guru mengaplikasikan metode atau strategi tersebut di kelas. Dalam kurun waktu tertentu, siswa diuji kembali dengan soal yang mengacu pada Standar Kompetensi Lulusan (SKL) Ujian Nasional dan proses diatas berulang kembali sebanyak 2 - 3 putaran sebelum pelaksanaan Ujian Nasional.

\section{METODOLOGI PENELITIAN}

Metode penelitian yang digunakan yaitu penelitian deksriptif. Pada model pendampingan ini tahap perencanaan akan dilakukan dengan merumuskan metode evaluasi yang digunakan yaitu dengan cara penyusunan instrumen tes yang mengacu pada SKL yang telah ditetapkan. Pengumpulan data dilakukan dengan pelaksanaan tes kepada siswa. Selanjutnya dilakukan tahap verifikasi dan analisis data dengan menggunakan statistika deskriptif dan diinterpretasikan. Teknik evaluasi pendidikan yang digunakan yaitu teknik tes pilihan ganda.

Teknik analisis untuk mengukur kualitas alat evaluasi secara kualitatif meliputi analisis terhadap aspek kualitatif soal meliputi; materi soal (relevansi dengan tujuan evaluasi, relevansi dengan kurikulum, dan tingkat taxon), konstruksi, bahasa atau keterbacaan, kunci jawaban dan pedoman penskorannya. Sedangkan secara kuantitatif dengan cara melakukan validitas dan reliabilitas dari instrumen yang disusun.

Setelah tes dilakukan tahap selanjutnya adalah pengolahan data. Data diolah dengan bantuan software DMR (Digital Mark Reader). Berdasarkan pengolahan data hasil tes diagnostik akan diperoleh data kelemahan dan kekuatan siswa per pokok/sub pokok bahasan pada mata pelajaran matematika. 


\section{HASIL DAN PEMBAHASAN}

Sebelum berlanjut ke uraian hasil dan pembahasan, akan diperlihatkan alur model pendampingan guru dalam pelaksanaan ujian nasional sebagai berikut:

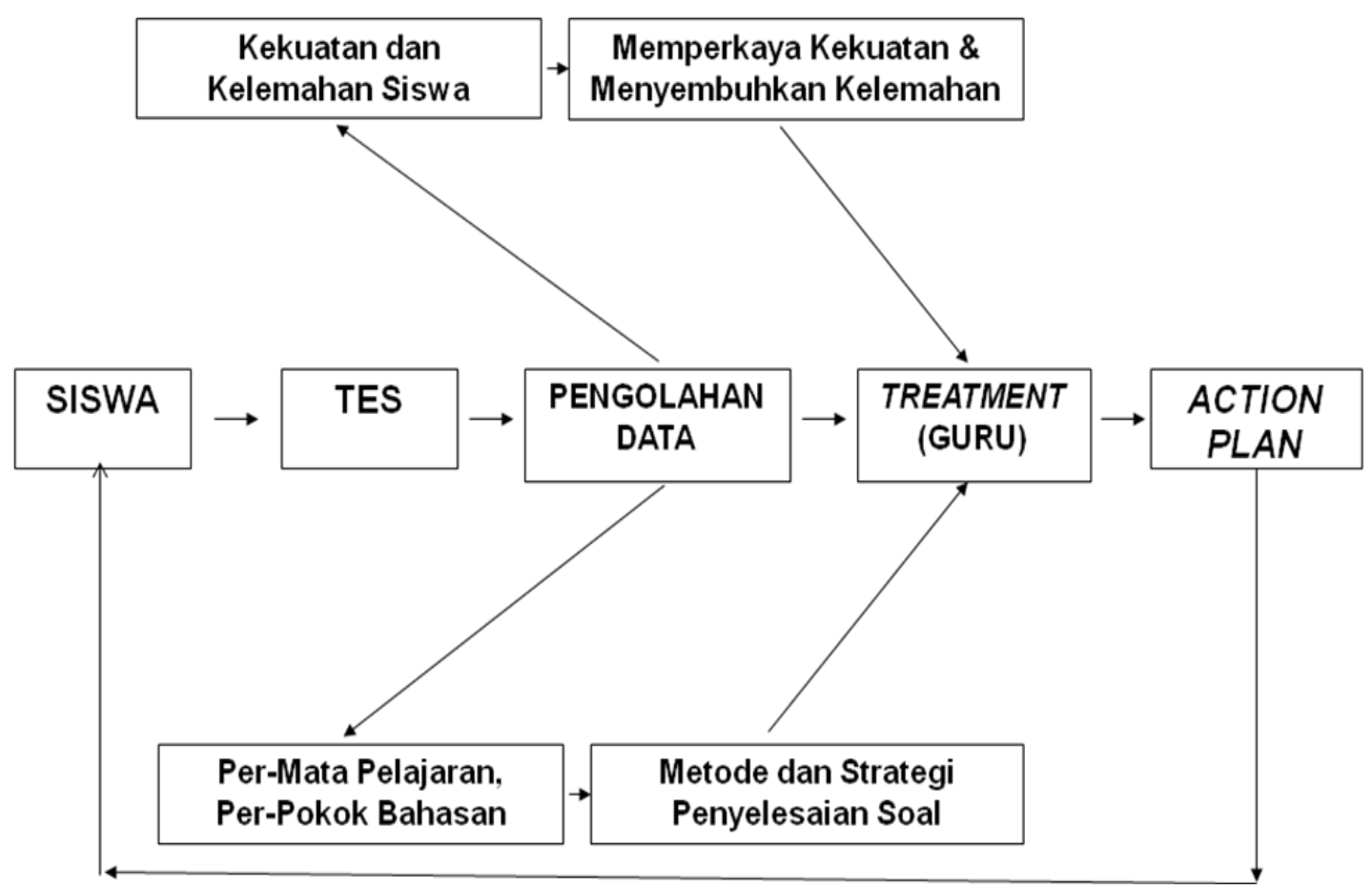

Gambar 1. Tes Diagnostik terhadap Siswa

\section{Tes Diagnostik Siswa}

Dalam model ini alat evaluasi yang digunakan adalah teknik tes dengan menggunakan seperangkat soal yang mengacu pada Standar Kompetensi Lulusan (SKL). menurut Ruseffendi (1980), proses pembelajaran diagnostik itu meliputi:

1. melihat kelemahan dan kekuatan anak secara umum dan khusus, serta memperkirakan penyebab kekuatan dan kelemahan itu.

2. merumuskan tujuan pembelajaran khusus (TPK) untuk pengajaran remedialnya.

3. mencari dan merumuskan cara - cara untuk memperkaya kekuatannya dan menyembuhkan kelemahannya.

4. melakukan penelitian secara terus menerus.

Berdasarkan konsep diatas hasil analisis data model pendampingan ini akan mengetahui letak kelemahan dan kekuatan siswa dalam pelajaran matematika. Adapun Contoh soal dan SKL yang digunakan adalah sebagai berikut: 
Tabel 1. Contoh soal dan Standar Kompetensi Lulusan (SKL)

\begin{tabular}{|c|c|c|c|c|}
\hline $\begin{array}{l}\text { No. } \\
\text { Soal }\end{array}$ & $\begin{array}{c}\text { STANDAR } \\
\text { KOMPETENSI } \\
\text { LULUSAN (SKL) }\end{array}$ & $\overline{U R A I A N}$ & INDIKATOR & $\overline{\text { Soal }}$ \\
\hline 1 & $\begin{array}{l}\text { Memahami } \\
\text { pernyataan dalam } \\
\text { matematika dan } \\
\text { ingkarannya, } \\
\text { menentukan nilai } \\
\text { kebenaran } \\
\text { pernyataan } \\
\text { majemuk, serta } \\
\text { mampu } \\
\text { menggunakan } \\
\text { prinsip logika } \\
\text { matematika dalam } \\
\text { pemecahan } \\
\text { masalah. }\end{array}$ & $\begin{array}{l}\text { Ingkaran } \\
\text { suatu } \\
\text { pernyataan. }\end{array}$ & $\begin{array}{l}\text { Siswa dapat } \\
\text { menentukan } \\
\text { ingkaran } \\
\text { suatu } \\
\text { pernyataan. }\end{array}$ & $\begin{array}{l}\text { 1. Ingkaran dari pernyataan : "Jika } \\
\text { semua murid lulus Ujian Nasional } \\
\text { maka ada murid yang tidak suka lagu } \\
\text { Ungu", adalah ...... } \\
\text { A. Semua murid lulus ujian } \\
\text { nasional dan semua murid juga } \\
\text { suka lagu ungu } \\
\text { B. Ada murid yang tidak lulus } \\
\text { ujian nasional walaupun ia suka } \\
\text { lagu ungu } \\
\text { C. Jika ada murid yang tidak lulus } \\
\text { ujian nasional maka ia tidak } \\
\text { suka lagu ungu } \\
\text { D. Ada murid yang tidak suka lagu } \\
\text { ungu maka ia lulus ujian } \\
\text { nasional } \\
\text { E. Jika ada murid yang suka lagu } \\
\text { ungu maka semua murid lulus } \\
\text { ujian nasional }\end{array}$ \\
\hline 2 & $\begin{array}{l}\text { Memahami } \\
\text { pernyataan dalam } \\
\text { matematika dan } \\
\text { ingkarannya, } \\
\text { menentukan nilai } \\
\text { kebenaran } \\
\text { pernyataan } \\
\text { majemuk, serta } \\
\text { mampu } \\
\text { menggunakan } \\
\text { prinsip logika } \\
\text { matematika dalam } \\
\text { pemecahan } \\
\text { masalah. }\end{array}$ & $\begin{array}{l}\text { Penarikan } \\
\text { kesimpulan }\end{array}$ & $\begin{array}{l}\text { Siswa dapat } \\
\text { menentukan } \\
\text { penari-kan } \\
\text { kesimpulan } \\
\text { suatu } \\
\text { pernyataan. }\end{array}$ & $\begin{array}{l}\text { 2. Diketahui premis-premis sebagai } \\
\text { berikut : } \\
\text { 1. jika Budi lulus ujian maka Budi } \\
\text { kuliah diperguruan tinggi } \\
\text { 2. Jika Budi kuliah di perguruan } \\
\text { tinggi maka Budi menjadi sarjana } \\
\text { 3. Budi tidak menjadi sarjana } \\
\text { Kesimpulan yang sah dari ketiga } \\
\text { premis di atas adalah : } \\
\text { A. Budi kuliah di perguruan tinggi } \\
\text { B. Nilai Budi tidak baik } \\
\text { C. Budi tidak mempunyai biaya } \\
\text { D. Budi tidak lulus ujian } \\
\text { E. Budi bekerja di suatu } \\
\text { perusahaan }\end{array}$ \\
\hline 3 & $\begin{array}{l}\text { Memahami konsep } \\
\text { yang berkaitan } \\
\text { dengan aturan } \\
\text { pangkat, akar, dan } \\
\text { logaritma, fungsi } \\
\text { aljabar sederhana, } \\
\text { persamaan dan } \\
\text { pertidaksamaan } \\
\text { kuadrat, } \\
\text { persamaan } \\
\text { lingkaran dan } \\
\text { persamaan garis }\end{array}$ & $\begin{array}{l}\text { Konsep } \\
\text { aturan } \\
\text { pangkat, } \\
\text { akar }\end{array}$ & $\begin{array}{l}\text { Siswa dapat } \\
\text { menyelesaikan } \\
\text { permasalahan } \\
\text { yang berkaitan } \\
\text { dengan pangkat } \\
\text { dan akar }\end{array}$ & $\begin{array}{l}\text { Nilai dari } \frac{7 x^{-\frac{3}{2}} \sqrt[6]{y^{5}}}{\left(x^{\frac{5}{4}}-6 y^{-\frac{1}{3}}\right) x^{-2}} \text { untuk } \\
\mathrm{x}=4 \text { dan } \mathrm{y}=27 \text { adalah } \ldots \ldots \ldots \ldots . . . \\
\text { A. }(1+2 \sqrt{2}) 9 \sqrt{2} \\
\text { B. }(1+2 \sqrt{2}) 9 \sqrt{3} \\
\text { C. }(1+2 \sqrt{2}) 18 \sqrt{3} \\
\text { D. }(1+2 \sqrt{2}) 27 \sqrt{2}\end{array}$ \\
\hline
\end{tabular}




\begin{tabular}{|c|c|c|c|c|}
\hline 4. & $\begin{array}{l}\text { singgungnya, suku } \\
\text { banyak, sistem } \\
\text { persamaan linear, } \\
\text { program linear, } \\
\text { matriks, vektor, } \\
\text { transformasi } \\
\text { geometri, barisan } \\
\text { dan } \\
\text { deret, serta mampu } \\
\text { menggunakannya } \\
\text { dalam pemecahan } \\
\text { masalah. }\end{array}$ & $\begin{array}{l}\text { logaritma, } \\
\text { fungsi } \\
\text { aljabar } \\
\text { sederhana, }\end{array}$ & $\begin{array}{l}\text { Siswa dapat } \\
\text { menyelesaikan } \\
\text { permasalahan } \\
\text { yang berkaitan } \\
\text { dengan } \\
\text { logaritma dan } \\
\text { fungsi aljabar } \\
\text { sederhana }\end{array}$ & $\begin{array}{l}\text { E. }(1+2 \sqrt{2}) 27 \sqrt{3} \\
\text { Nilai } x \text { yang memenuhi persamaan } \\
{ }^{2} \log { }^{2} \log \left(2^{x+1}+3\right)=1+{ }^{2} \log x \text { adala } \\
\text { h: }{ }^{2} \log 3 \\
\quad \text { A. }{ }^{3} \log 2 \\
\text { C. } \log \frac{2}{3} \\
\text { D. }-1 \text { atau } 3 \\
\text { E. } 8 \text { atau } \frac{1}{2}\end{array}$ \\
\hline 5. & & $\begin{array}{l}\text { persamaan } \\
\text { kuadrat }\end{array}$ & $\begin{array}{l}\text { Siswa dapat } \\
\text { menyelesaikan } \\
\text { permasalahan } \\
\text { yang berkaitan } \\
\text { dengan } \\
\text { persaman } \\
\text { kuadrat }\end{array}$ & $\begin{array}{l}\text { Diketahui akar-akar persamaan kuadrat } \\
2 \mathrm{x}^{2}+6 \mathrm{x}-5=0 \text { adalah } \mathrm{x}_{1} \text { dan } \mathrm{x}_{2} \text {. } \\
\text { Persamaan kuadrat baru yang akar- } \\
\text { akarnya } \frac{2}{x_{1}}+\frac{2}{x_{2}} \text { dan } \mathrm{x}_{1} \mathrm{x}_{2} \text { adalah } \\
\ldots \ldots \ldots \\
\text { A. } \mathrm{x}^{2}-19 \mathrm{x}-12=0 \\
\text { B. } 10 \mathrm{x}^{2}+\mathrm{x}-60=0 \\
\text { C. } 10 \mathrm{x}^{2}+19 \mathrm{x}+60=0 \\
\text { D. } 5 \mathrm{x}^{2}+19 \mathrm{x}-60=0 \\
\text { E. } 5 \mathrm{x}^{2}-12 \mathrm{x}-8=0\end{array}$ \\
\hline
\end{tabular}

Berdasarkan tabel SKL diatas disusun soal sebagai berikut:

1. Ingkaran dari pernyataan : "Jika semua murid lulus Ujian Nasional maka ada murid yang tidak suka lagu Ungu", adalah

A. Semua murid lulus ujian nasional dan semua murid juga suka lagu ungu

B. Ada murid yang tidak lulus ujian nasional walaupun ia suka lagu ungu

C. Jika ada murid yang tidak lulus ujian nasional maka ia tidak suka lagu ungu

D. Ada murid yang tidak suka lagu ungu maka ia lulus ujian nasional

E. Jika ada murid yang suka lagu ungu maka semua murid lulus ujian nasional

2. Diketahui premis-premis sebagai berikut :

1. jika Budi lulu ujian maka Budi kuliah diperguruan tinggi

2. Jika Budi kuliah di perguruan tinggi maka Budi menjadi sarjana

3. Budi tidak menjadi sarjana

Kesimpulan yang sah dari ketiga premis di atas adalah :

A. Budi kuliah di perguruan tinggi

B. Nilai Budi tidak baik

C. Budi tidak mempunyai biaya

D. Budi tidak lulus ujian

E. Budi bekerja di suatu perusahaan 
3. Nilai dari $\frac{7 x^{-\frac{3}{2}} \sqrt[6]{y^{5}}}{\left(x^{\frac{5}{4}}-6 y^{-\frac{1}{3}}\right) x^{-2}}$

untuk $x=4$ dan $y=27$ adalah
A. $(1+2 \sqrt{2}) 9 \sqrt{2}$
B. $(1+2 \sqrt{2}) 9 \sqrt{3}$
C. $(1+2 \sqrt{2}) 18 \sqrt{3}$
D. $(1+2 \sqrt{2}) 27 \sqrt{2}$
E. $(1+2 \sqrt{2}) 27 \sqrt{3}$

4. Nilai $x$ yang memenuhi persamaan ${ }^{2} \log { }^{2} \log \left(2^{x+1}+3\right)=1+{ }^{2} \log x$ adalah :
A. ${ }^{2} \log 3$
B. ${ }^{3} \log 2$
C. $\log \frac{2}{3}$
D. -1 atau 3
E. 8 atau $\frac{1}{2}$

5. Diketahui akar-akar persamaan kuadrat $2 x^{2}+6 x-5=0$ adalah $x_{1}$ dan $x_{2}$. Persamaan kuadrat baru yang akar-akarnya $\frac{2}{x_{1}}+\frac{2}{x_{2}}$ dan $\mathrm{x}_{1} \mathrm{x}_{2}$ adalah ..........
A. $x^{2}-19 x-12=0$
B. $10 x^{2}+x-60=0$
C. $10 x^{2}+19 x+60=0$
D. $5 x^{2}+19 x-60=0$
E. $5 x^{2}-12 x-8=0$,
dan seterusnya. 
Analisis Data Kelemahan Siswa per Pokok/Sub Pokok Bahasan dalam Mata Pelajaran Matematika

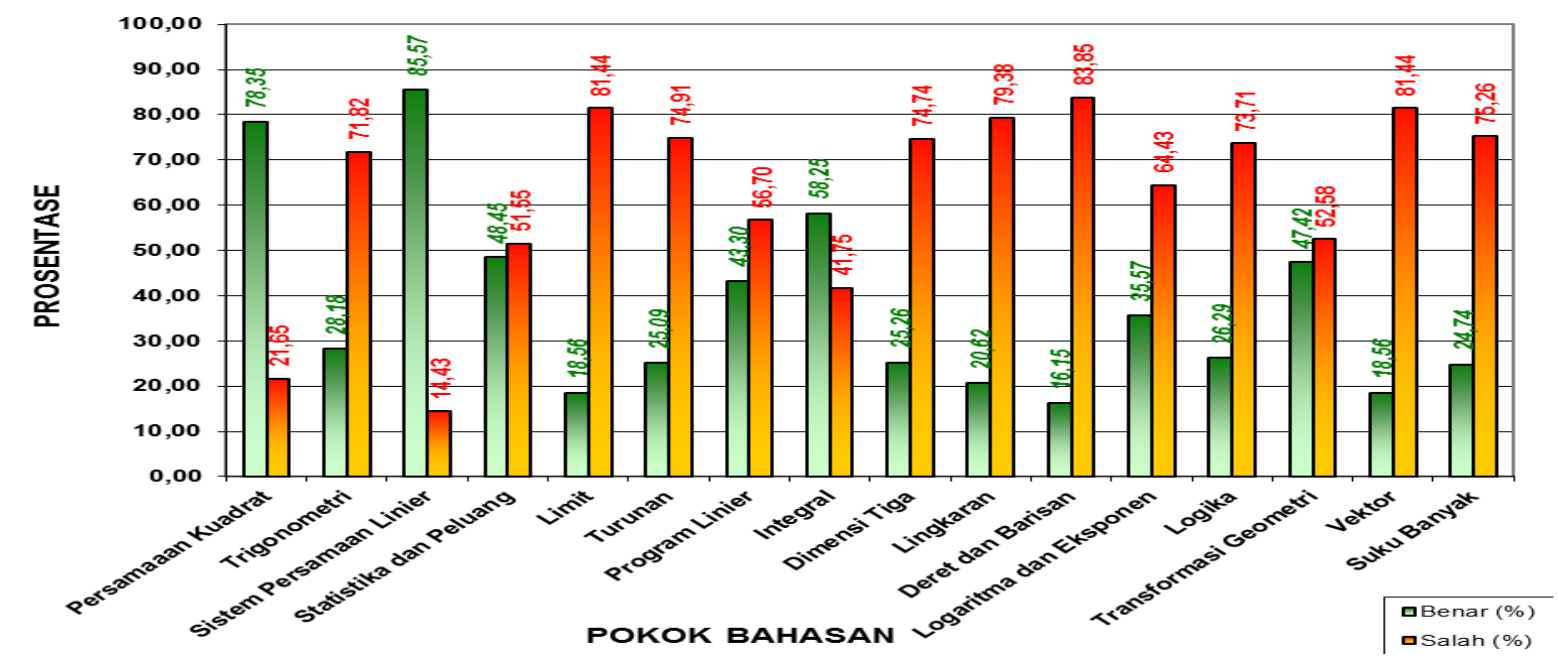

Gambar 2. Diagram Hasil Analisis yang Memuat Profil Kemampuan Siswa per Pokok Bahasan untuk Mata Pelajaran Matematika.

Selain Gambar 2, untuk memudahkan analisis, disajikan pula data per siswa termasuk didalamnya kecenderungan jawaban siswa dari option yang diberikan, dalam tabel berikut ini.

Tabel 2. Hasil Tes Diagnostik Individual Siswa per Option

\begin{tabular}{|c|c|c|c|c|c|c|c|c|c|c|c|c|}
\hline \multirow[t]{3}{*}{ NO } & & NAMA & \multicolumn{8}{|c|}{ NOMOR SOAL } & \multirow[t]{3}{*}{ BENAR } & \multirow[t]{3}{*}{ NILAI } \\
\hline & \multirow[t]{2}{*}{ ID } & & 1 & 2 & 3 & 4 & 5 & $\ldots$ & 29 & 30 & & \\
\hline & & KUNCI & B & $\mathbf{A}$ & $\mathbf{A}$ & B & B & ... & D & $\mathbf{A}$ & & \\
\hline 1 & 070105 & DAHLIA & 1 & 0 & 1 & 1 & 0 & ... & 0 & 0 & 14 & 4.67 \\
\hline 2 & 070121 & NURYANTI & 1 & 0 & 1 & 0 & 0 & ... & 0 & 0 & 13 & 4.33 \\
\hline 3 & 070134 & YULIANTI W & 1 & 0 & 1 & 1 & 0 & $\ldots$ & 0 & 0 & 13 & 4.33 \\
\hline 4 & 070113 & IKETRISANA & 1 & 0 & 1 & 1 & 0 & ... & 0 & 0 & 12 & 4.00 \\
\hline 5 & 070102 & ANTON SUSANTO & 1 & 0 & 1 & 0 & 1 & ... & 0 & 0 & 12 & 4.00 \\
\hline$\ldots$ & $\ldots$ & $\ldots$ & $\ldots$ & $\ldots$ & $\ldots$ & $\ldots$. & $\ldots$ & & $\ldots$ & $\cdots$ & .... & $\ldots$ \\
\hline \multirow[t]{7}{*}{30} & 070112 & IDA MUSTAFIDAH & 0 & 1 & 1 & 0 & 0 & ... & 0 & 0 & 7 & 2.33 \\
\hline & & Kecenderungan Jawaban Siswa & & & & & & & & & & \\
\hline & & A & 0,21 & 0,18 & 0,62 & 0,03 & 0,68 & $\ldots$ & 0,00 & 0,06 & & \\
\hline & & B & 0,62 & 0,38 & 0,03 & 0,41 & 0,21 & $\ldots$ & 0,12 & 0,74 & & \\
\hline & & $\mathrm{C}$ & 0,12 & 0,18 & 0,15 & 0,26 & 0,03 & $\ldots$ & 0,85 & 0,15 & & \\
\hline & & $\mathrm{D}$ & 0,03 & 0,24 & 0,03 & 0,29 & 0,09 & $\ldots$ & 0,00 & 0,00 & & \\
\hline & & $\mathrm{E}$ & 0,03 & 0,03 & 0,18 & 0,00 & 0,00 & $\ldots$ & 0,03 & 0,03 & & \\
\hline
\end{tabular}

\section{Treatmen Guru}

Kegiatan selanjutnya adalah treatment bagi guru mata pelajaran Matematika. Kegiatan Treatment ini berbentuk workshops (diikuti oleh guru mata pelajaran) dengan input materi 
ditekankan pada pokok bahasan yang kurang dikuasai oleh siswa (kelemahan siswa) berdasarkan hasil pengolahan data, disertai dengan strategi pembelajarannya.

Contoh strategi pemecahan masalah yang diberikan pada saat treatmen adalah sebagai berikut:

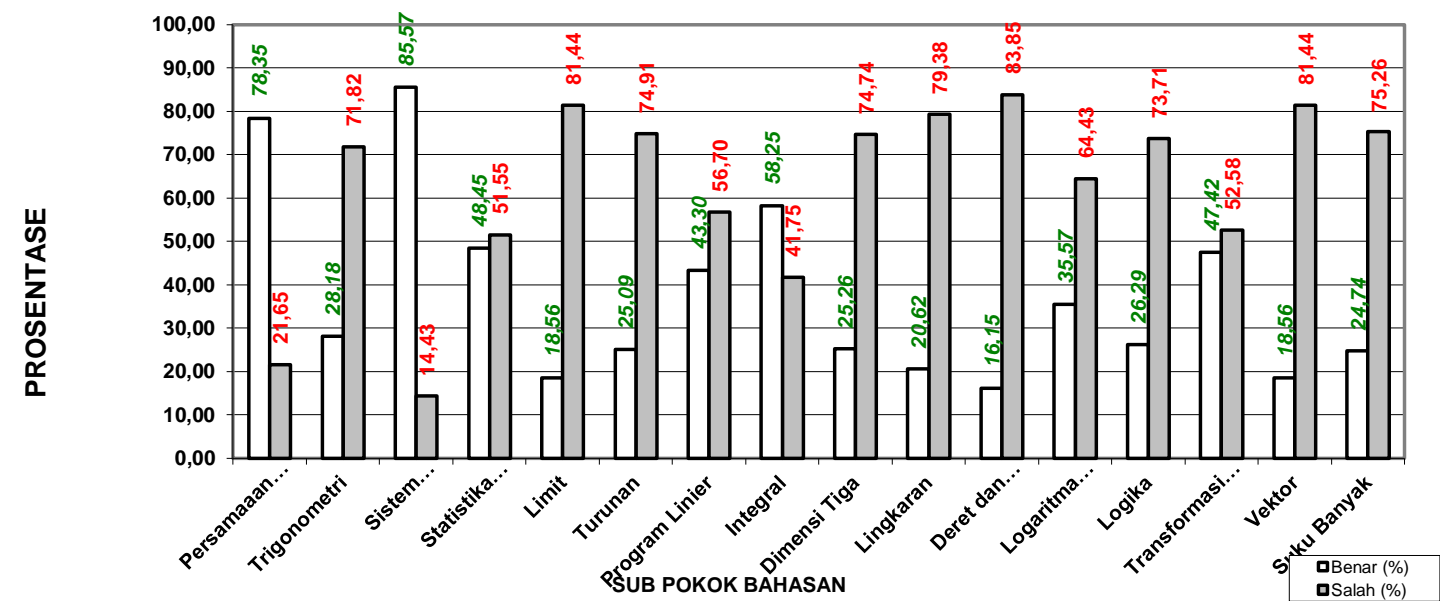

\section{Gambar 3. Persentase Kesalahan untuk Setiap Sub Pokok Bahasan Matematika SMA}

Dari Gambar 3, dapat dilihat bahwa prosentase kesalahan untuk setiap sub pokok bahasan matematika SMA masih cukup tinggi. Beberapa diantaranya adalah Logika, Limit, Suku Banyak, Turunan, Barisan dan Deret, Vektor, dan Lingkaran.

Masih cukup tingginya prosentase kesalahan hasil tes diagnostik I diatas, diduga disebabkan oleh beberapa faktor berikut:

1. Ada sub pokok bahasan yang belum diajarkan di sekolah. Misalnya Barisan dan Deret, sub pokok bahasan ini baru diajarkan di kelas XII Semester 2.

2. Ada materi - materi tertentu dalam mata pelajaran matematika yang tidak hanya membutuhkan ketelitian tapi juga berpikir abstrak, misalnya dimensi tiga.

3. Ketidaksiapan mental siswa dalam mengikuti tes. Keadaan mental juga mempengaruhi keberhasilan siswa dalam mengikuti ujian. Semakin siap mental siswa dalam menghadapi ujian, ia akan semakin tenang dan konsentrasi dalam mengerjakan soal, begitu pula sebaliknya.

4. Pemahaman terhadap soal dan strategi penyelesaian soal yang kurang dikuasai oleh siswa. 
Balitbang Depdiknas merumuskan beberapa keterampilan untuk meningkatkan kemampuan dalam memecahkan masalah matematika, yaitu:

1. memahami soal: memahami dan mengidentifikasi apa fakta atau informasi yang diberikan, apa yang ditanyakan, diminta untuk dicari, atau dibuktikan.

2. memilih pendekatan atau strategi pemecahan: misalkan mengambarkan masalah dalam bentuk diagram, memilih dan menggunakan pengetahuan aljabar yang diketahui dan konsep yang relevan untuk membentuk model atau kalimat matematika.

3. menyelesaikan model: melakukan operasi hitung secara benar dalam menerapkan strategi, untuk mendapatkan solusi dari masalah.

4. menafsirkan solusi: memperkirakan dan memeriksa kebenaran jawaban, masuk akalnya jawaban, dan apakah memberikan pemecahan terhadap masalah semula.

Dari gambaran umum hasil tes, identifikasi faktor penyebab, dan rumusan Depdiknas diatas, penulis menawarkan beberapa alternatif solusi:

1. Materi pelajaran matematika kelas XII sesegera mungkin dituntaskan (misalnya melalui jam pengayaan).

2. Materi disampaikan dengan menarik dan sederhana, misalnya:

- penyederhanaan isi/materi pembelajaran untuk pokok bahasan tertentu.

- penyederhanaan cara penyajian (misalnya: menggunakan gambar, model, skema, grafik, memberikan rangkuman yang sederhana dan lain - lain).

3. Pemberian tugas dan bimbingan secara khusus bagi siswa yang belum atau mengalami kesulitan dalam pokok bahasan tertentu.

4. Pemberian strategi penyelesaian soal untuk setiap pokok bahasan yang familier di Ujian Nasional.

\section{Penyusunan Action Plan}

Di akhir workshops, guru menyusun action plan untuk mengatasi kelemahan siswa berdasarkan data hasil analisis dan input materi yang telah diperolehnya dari fasilitator.

Contoh Format Action Plan yang akan diisi oleh para guru adalah sebagai berikut: 
Tabel 3. Format Action Plan

ACTION PLAN

TINDAK LANJUT HASIL TES DIAGNOSTIK KABUPATEN CIREBON 2007

NAMA SEKOLAH :
ALAMAT :
MATA PELAJARAN :

\begin{tabular}{|l|l|l|l|l|l|l|}
\hline NO & $\begin{array}{c}\text { POKOK } \\
\text { BAHASAN }\end{array}$ & MASALAH & $\begin{array}{c}\text { ALTERNATIF } \\
\text { PEMECAHAN } \\
\text { MASALAH }\end{array}$ & TARGET & WAKTU & $\begin{array}{c}\text { PENANGGUNG } \\
\text { JAWAB }\end{array}$ \\
\hline & & & & & & \\
\hline & & & & & & \\
\hline & & & & & & \\
\hline
\end{tabular}

\section{KESIMPULAN}

Berdasarkan uraian konsep, dan pelaksanaan dari model pendampingan guru dalam menghadapi Ujian Nasional, khususnya mata pelajaran matematika, dapat disimpulkan bahwa alangkah baiknya jika dimunculkan berbagai model atau metode untuk mengoptimalkan persiapan siswa/guru dalam menghadapi Ujian Nasional sedemikian hingga siswa, guru, sekolah dan masyarakat tidak lagi fobia terhadap penyelenggaraan Ujian Nasional. Salah satu model yang dimunculkan adalah Program Pendampingan Guru dalam Menghadapi Pelaksanaan Ujian Nasional. Selain itu, metode/model apapun yang digunakan dalam kegiatan persiapan siswa/guru mengahadapi UN akan sangat ditentukan keberhasilannya oleh keseriusan belajar siswa dan kesungguhan guru dalam membimbing siswanya berdasarkan data kelemahan dan kekuatan siswa yang telah diperoleh dari tes diagnostik. 
Jurnal PRISMA Universitas Suryakancana

\section{REFERENSI}

Ruseffendi E.T. (1980). Pengajaran Matematika Modern. Bandung: Tarsito

Kumpulan Soal Ujian Nasional dan Seleksi Masuk PTN 